\title{
EU ENLARGEMENT:WHAT DOES IT CHANGE FOR THE EUROPEAN ECONOMIC GEOGRAPHY?
}

\author{
Sébastien Dupuch, Hugues Jennequin \\ and El Mouhoub Mouhoud*
}

Centre d'Économie de l'Université Paris Nord

This paper evaluates the effects of the enlargement of the EU to the Central and Eastern European Countries (CEECs), focusing on agglomeration and industrial specialisation patterns in Europe. We first present the theoretical debate based on the New Economic Geography models. The outcome is that, in spite of the lack of labour mobility within the EU, a core periphery schema is expected to occur as a result of vertical linkages. Then, we provide evidence on real and structural convergence and FDI trends in the enlarged EU. We show that sectoral divergence resulting from agglomeration economies is likely to persist through a high-skilled core attracting increasing intensive activities and a low-skilled periphery. By discussing two alternative scenarios in terms of international specialisation, we show that Central European countries are likely to follow a "Spanish model" based on catching-up, industrial diversification and intra-industry trade, while Eastern countries could durably lag behind. Similarly, the Mediterranean economies, which are engaged in the EuroMediterranean partnership, exhibit very complementary international specialisation relative to the EU through resource- and labour-intensive industries.

$\mathrm{E}$ ach new step of the European unification brings about concerns relative to the impact of regional integration on production structures within the Member States. The economic geography of Europe faces some new challenges with the imminent enlargement to the Central and Eastern European Countries (CEECs) and the implementation of association agreements with Southern and Eastern Mediterranean Countries (SEMCs) ${ }^{1}$ : how will the location of activities

* CEPN CNRS UMR n 71-15, Université de Paris 13, UFR Sc. Economiques, 99 av. JB Clément-93430 Villetaneuse, dupuch@seg.univ-paris13.fr, jennequin@seg.univ-paris13.fr. mouhoud@seg.univ-paris13.fr

1. On 1st May 2004, the EU will be supplemented with ten countries: the Czech Republic, Cyprus, Estonia, Hungary, Latvia, Lithuania, Malta, Poland, Slovakia and Slovenia. We only deal with the CEECs including Bulgaria and Romania whose accession is postponed until 2007 or 2008, according to the latest declarations by EU officials. Because of data limitations, we restrict our sample of Mediterranean economies to five countries: Algeria, Egypt, Morocco, Tunisia and Turkey. 
and specialisation patterns be affected by the accession of countries that exhibit various production structures and remote levels of development? Will industrial agglomeration processes in an integrated area be stronger than dispersion and diversification forces among participating nations? What lessons can we derive from the experience of the preceding waves of enlargement of the EU?

This article aims at discussing two opposite scenarios as regards future prospects of the European economic geography. According to the first one, the predominance of intra-industry trade within European nations results in weak specialisation in terms of production and employment. Thus, it privileges the optimistic view of overall economic convergence between the EU Member States. For example, the Emerson report (1990) underlines the current macroeconomic convergence of European countries and proves to be hopeful when considering the impact of monetary integration. This report considers that "EMU would reduce the incidence of country-specific shocks". In the same vein, Frankel and Rose (1998) argue that "increased integration may result in more highly correlated business cycles because of common demand shocks or intra-industry trade". The risks of asymmetric shocks and increased spatial disparities resulting from strong relocation of activities are thus smaller than expected. This kind of prediction suggests a minimal common framework of well-developed redistributive policies across European nations.

Another point of view provided by the United States experience has been developed by some economists like Paul Krugman. According to the New Economic Geography (NEG) framework, he argues that deeper integration would translate into increased specialisation resulting from inter-industry comparative advantages. The Member States would specialise in a small number of activities and therefore would be more sensitive to asymmetric shocks. In NEG models, economic integration leads to a spatial core-periphery schema, resulting in higher agglomeration and increased specialisation detrimental to peripheral countries (Krugman, 1991a).

A French report by the Commissariat Général du Plan (CGP, 1999) took a position between these two opposite points of view. It concluded that countries entering into the EMU were rather diversified and would preserve most of their activities. Intra-European trade is mainly of intra-industry type but traded goods within the EU are predominantly vertically differentiated. Therefore, EU countries face structural and technological asymmetries, which can lead to more agglomerated production structures. However, polarisation is less likely to occur across nations where production structures are rather homogeneous than across regions, which are diverging within all European nations. 
In this article, we explicitly include the candidate countries and the Mediterranean economies in the discussion. We ask if the new incumbents are more likely to follow an intra-industry specialisation path or, conversely, a deeper specialisation according to traditional comparative advantages. In the first case, the CEECs would experience more industrial diversification with increasing intra-industry trade that characterises developed or catching-up economies. In the second case, the risks of asymmetric shocks would be stronger in countries that develop trade relations with the EU based on their specialisation in traditional labourintensive industries. When confronting our assumptions with empirical evidence, we find that two different groups of countries can be drawn up according to production structures, trade openness and FDI inflows. Only Central European countries tend to develop intra-industry trade with the EU countries and are likely to catch up with the EU average while the more peripheral countries in Eastern Europe and the Mediterranean economic partners still exhibit high levels of specialisation in traditional sectors. As a result, the European economic geography indicates a persistent core-periphery structure.

The article is organised as follows. First, we put forward the impact of regional integration on the distribution of industrial activities across Member States in a theoretical perspective. In a second section, we gather the main stylised facts on real and structural convergence between candidate countries and the EU, and discuss the likely effects of FDI on specialisation dynamics. The third section of the article evaluates how much the Member States are specialised in an enlarged Union and the last one brings some elements of comparison with the SEMCs.

\section{The theoretical framework}

Economists identify two different sources of potential benefits from the EU integration: an improvement in the allocation of resources and the accumulation of further resources (Baldwin, 1994). However, the overall effects of deeper integration on the national economies are more ambiguous and depend on regional characteristics. Thus, uneven economic development can result from unevenly distributed natural resources and endowments. This distribution depends on exogenous regions' natural advantages. Although relevant in some specific cases (mining or fishing activities), this analysis cannot explain the main features of location and specialisation patterns in Europe.

The New Economic Geography (NEG) ensuing from the standard location theory describes economic forces which inflect the geographical distribution of activities. One of the main contributions of NEG 
models is to endogenise the market size. A confrontation between dispersion and agglomeration forces appears, depending on the integration level ${ }^{2}$.

These forces result from the interactions between imperfect competition, economies of scale and agglomeration externalities ${ }^{3}$. Firms and workers trade off between advantages from agglomeration economies and mobility and transaction costs. The regional integration, assimilated to a decrease in transaction costs, encourages firms to concentrate in order to benefit from economies of scale. As in "new trade theory" models, increasing-returns-intensive sectors (so-called "modern" sectors) will be disproportionately present in regions with good market access (Krugman, 1980). Moreover, associated with this home market effect, NEG models show that the market size increases as manufacturing agglomerates. Consequently, a cumulative causation can occur under some conditions.

Two kinds of NEG models explain the agglomeration process based on two different mechanisms. First, the Core-Periphery model (Krugman, 1991b) assumes labour mobility across regions. It shows that agglomeration of the modern sector is the unique stable equilibrium as soon as transaction costs are sufficiently low. In this case, the cumulative gains increase for both geographically mobile consumers and industrial firms (see box 1$)^{4}$.

According to this model, the Eastern enlargement is expected to induce higher agglomeration towards the core European regions. So, most of the CEECs would be marginalized. However, the European experience exhibits some specificities that moderate the probability that such an agglomeration process occurs. To a large extent, the geographical mobility assumption used in core-periphery models is irrelevant in the European context (Bailly et al., 2003). These models are more suited in the context of regional economies within nations than for studying international integration. Without labour migration, concentration of firms cannot induce any agglomeration of workers. The core-periphery cumulative causation disappears. The effects of European integration on location pattern are better explained by a second generation of NEG models.

2. See Ottaviano and Puga (1998) for a survey of NEG literature and Fujita et al. (1999) Neary (2001), Ottaviano and Thisse (2001 and 2003) or Baldwin et al. (2003) for more details.

3. All these externalities describe two kinds of interactions. On the one hand, so-called "technological externalities" occur outside the markets and act directly on the consumers' utility function or the firms' production function. Their formalisation is rare because difficult (see Rieber and Tran, 2001 for an example). On the other hand, so-called "pecuniary externalities" imply market-mechanisms-based interactions.

4. This result from the core-periphery model can be found under alternative assumptions: imperfect labour mobility (Ludema and Wooton, 1999), differentiating skills levels in the modern sector (Amiti and Pissarides, 2002), taste heterogeneity (Tabuchi and Thisse, 2001) or forwardlooking expectations (Baldwin, 2001). All of these assumptions have no qualitative effect on the core-periphery model's behaviour. 


\section{Forward and backward linkages and NEG models}

\section{NEG models' assumptions}

NEG models usually combine two regions and two sectors. Regions are identical in tastes, technologies and endowments but sectors differ. The agricultural sector produces a homogeneous output under constant returns to scale and perfect competition. An agricultural good is freely traded so its price is identical in both regions. The manufacturing sector is imperfectly competitive and produces many varieties under increasing returns to scale. Following Dixit and Stiglitz (1977), production of any variety in the same proportion in any region requires the same fixed and variable quantities of input with a linear cost function. Moreover, each firm produces only one variety.

Considering two regions requires focusing on trade costs between them. Under trade costs, NEG models not only include physical transport costs, but also monetary conversion, linguistic and cultural differences or specific norms. They are formalised as "iceberg" transport technology, initially introduced by Samuelson, in which only a fraction of a good arrives in the other region. The remaining production is consumed by transport necessities and importing more and more differentiated goods from other countries induces a price index increase.

The forward and backward linkages: description

The equilibrium location of firms is caused by interactions between centrifugal and centripetal forces depending on the transaction costs level. The centripetal (centrifugal) forces include all economic relations promoting concentration (dispersion) of economic activities. The centripetal forces can be self-sustaining. They constitute a cumulative causation then recalling Myrdal's concept. A change in a variable induces an adjustment in another variable, which in turn reinforces the first change.

Each of the forward and backward linkages describes one part of these two causal elements. The forward linkages depict how an agent is linked to its suppliers while the backward linkages illustrate how an economic agent is linked to its customers.

Why agglomeration occurs in the core-periphery models?

In a core-periphery model with mobile workforce, the cumulative causation takes place between the industrial firms and the consumers. Thus, the forward linkage explains how industrial agglomeration incites workers to migrate. Manufacturing concentration generates both a decrease in the regional price index (the share of imported goods decreases) and an increase in the regional nominal wage (following increasing competition). The regional real wage increase attracts more workers. This forward linkage takes place through an income effect.

Consecutively, migration induces a growing of industrial expenditures through the growth of regional income. This home market effect attracts industrial firms and constitutes the backward linkage.

Why agglomeration occurs in the vertical linkage models?

The vertical linkage models assume geographically immobile workers. The cumulative causation then differs. An input-output structure of production is introduced in the industrial sector. We distinguish between upstream-supplier firms and downstream-customer firms. Consequently, the forward (backward) linkage describes how agglomeration of supplier (customers) firms induces concentration of customers (supplier) firms. 
The forward linkage depicts a cost effect: more upstream firms in a location generate an increased variety of intermediate goods at a lower price through the newly exploited externalities. Then producers of final goods are attracted. The following backward linkage is a demand effect. Concentration of more downstream firms in this same location has two complementary consequences. On the one hand, it increases the regional wage. On the other hand, production by the relocated firm is no longer imported and consumers benefit from the disappearance of trade costs for this new variety. In the end, regional manufacturing expenditures rise, attracting more upstream firms.

The Vertical-Linkage models (Krugman and Venables, 1995; Venables, 1996) describe another agglomeration process based on two main relationships between these firms. The backward linkages mean that firms gain from being located close to their customers. This link is related to a demand effect. The forward linkages depict the firms' advantages from being located close to their suppliers. This is a production cost effect. Downstream firms use upstream firms' production as an intermediate input. Clustering of European activities is explained not only by the access to customers but also by the access to suppliers through an input-output structure described by Hirschman (1958). Firms take advantage from increasing returns to scale as trade costs on imported goods decrease sharply. Then, forward and backward linkages specific to these models succeed in explaining the agglomeration process without labour mobility (see box 1 ).

Both vertical-linkage and core-periphery models conclude that further integration leads to more agglomeration. However, this relation is non-monotonic. Industrial agglomeration causes a regional wage differential. Now, the immobility of workforce cannot equal the regional remuneration and wage competition becomes a centrifugal force. At low trade costs, firms become more and more sensitive to cost differentials, leading the "modern" sector to spread out (Puga, 1999). When the first stages of integration occur, the forward and backward linkages induce a manufacturing clustering which is self-sustaining. A coreperiphery pattern appears and entails differences in regional wages. In the last stages of integration, this wage differential can be enough to make a peripheral location profitable. Symmetry takes place again where the labour intensive activities relocate in low-cost regions.

Consequences of such models for the EU enlargement are noteworthy and depend on the initial integration level. Further integration could increase the probability that industry spreads out as a result of wage differentials among nations. Southern European countries should attract low-skilled intensive industries while the highskilled intensive activities would remain in the core. Thus, divergence in income from the core-periphery pattern is likely to be followed by a sectoral divergence across the European regions. 
This result is similar when both cumulative causations are associated. In a tri-sectoral model, Jennequin (2003) associates industrial and Knowledge Intensive Based Services (KIBS) which are supposed to produce under increasing returns to scale with differentiated output. An input-output structure is assumed between them. The author proves that upstream services activities employing high-skilled mobile workers play a significant role in the design of international economic geography. The CEECs could suffer from future migration of their highly-skilled workforce and experience strong relocation of activities in favour of core countries, both in the KIBS and manufacturing production.

The NEG literature provides further conclusions about the forthcoming enlargement. A model by Puga and Venables (1999) shows that catching-up can occur by waves of industrialisation when integration includes more than two countries. Assuming exogenous technical progress, industrial centres tend to develop and may become too large to be restricted to their initial location. When wage differentials are sufficiently high, industry spreads to another country to benefit from low labour costs and economies of scale. More specifically to Eastern countries, the Manzocchi and Ottaviano's model (2001) underlines the role of productivity in the transition process. They prove that deeper integration associated with convergence in the productivity levels would enable them to increase their national income, to attract a growing number of investments in the capital-intensive sectors and to upgrade their international specialisation in these sectors.

In addition to these theoretical works, Computational General Equilibrium (CGE) models are used in order to evaluate NEG models' conclusions and estimate the effects of the future enlargement on the European economies ${ }^{5}$. A CGE model by Forslid et al. (2002a) assumes that the enlargement will induce an increase in the CEECs' productivity level $^{6}$. Without considering investment-related effects, real income would increase by $15 \%$ on average as a result of a $5 \%$ increase in productivity level. These productivity-related gains could prove to be an efficient remedy against exclusion. However, considering the uneven success in the transition process, the Balkan countries and, to a lesser extent, the Baltic countries seem to suffer from weak productivity gains. This point can partly explain current divergence patterns between Eastern countries. Nevertheless, the relation between integration and real income materialises through productivity gains. When the authors

5. Most of CGE models are characterised by monopolistic competition and an input-output structure. Some simulations concern the EU integration in the nineties before enlargement. For example Francois (2002) simulates a reduction in trade costs corresponding to $2 \%$ of the value of trade. The gains in national income rise to $0.34 \%$ on average in the EU. They are higher for the 1995 new members and increase with the workers' mobility. Forslid et al. (2002b) find a non-monotonic relation between trade costs and the distribution of sectors characterised by increasing returns to scale and substantial intra-industry linkages.

6. Selected countries are Bulgaria, the Czech Republic, Hungary, Poland, Romania, Slovakia and Slovenia. 
directly simulated the effect of a $5 \%$ decrease in trade costs, growth in real income is estimated at 3.3\% and exports growth at 29\%.

In another work by Baldwin et al. (1997) Eastern integration is assimilated to a $10 \%$ decrease in trade costs, related both to the Single Market access and to the adoption of the EU's common external tariff. The real income should rise by $1.5 \%$ and exports from the CEECs by $25 \%$ (respectively by $0.2 \%$ and $1.5 \%$ in the EU). Consequently, the CEECs would catch up with the EU. The authors also suggest that the gains from the decrease of the CEECs risk premium would largely dominate all other integration benefits. Moreover, inside the EU, the core countries (Germany, France, the United Kingdom) get two-thirds of the estimated gains. More recently, Bchir and Maurel (2002) examine several alternative scenarios on the possible costs and benefits from the EU enlargement. Overall effects are rather limited for EU countries while the main impact is expected for Eastern countries.

However, all these benefits coming from the enlargement are highly sensitive to the necessarily simplified CGE models' structure and to the size of the decrease in trade costs. Only intuitions can be provided. In the same way, the distribution of expected gains across countries and sectors is insufficiently explained.

All this literature seems to indicate the feasibility of catching-up for the CEECs. However, many uncertainties remain. How will integration affect productivity and investment? Should we expect deeper sectoral divergence as a result of the enlargement? Conclusions arising from theories and simulations need to be supported by further analysis of location patterns within the enlarged EU. Prior to their accession in the EU, what are the main stylised facts about international specialisation of CEECs? The EU enlargement is likely to modify in many ways the future European economic geography. The next section investigates the main features of accession countries in real and structural terms. In particular, we insist on FDI-related impacts on specialisation patterns.

\section{What is the impact of the enlargement on EU specialisation and location patterns?}

\section{I. Real and structural convergence: stylised facts for CEECs}

At the beginning of the transition towards a market-based economy, mass privatisation and macroeconomic stabilisation programmes were implemented in CEECs. Meanwhile, the former USSR economically and politically collapsed and the first trade agreements with EEC (the EU's predecessor) were adopted. As a consequence, the CEECs' trade flows 
were largely redirected towards the EU countries thanks to proximity advantages and cultural links. In 2000, the EU members took around two thirds of the CEECs exports whereas they accounted for only $50 \%$ in 1993.

The question of their potential for economic catching-up becomes crucial with the formal integration of these countries into the EU. In terms of per capita GDP, the newcomers lag behind EU members more than did Spain, Greece and Portugal when they joined the EEC (table 1). Slovenia, by far the most advanced country among CEECs, reaches $70 \%$ of EU per capita GDP compared with an average of $45 \%$ in the other Central and Eastern European countries. These countries are engaged in a slow convergence process towards the EU as their GDP growth rates have not largely suffered from the decline in the world economy. In the more peripheral countries, differences in economic levels are much more pronounced. However, the Baltic States have experienced high growth rates for several years while Bulgaria and Romania still have per capita GDP levels under $30 \%$ of the EU average.

\section{PPP per capita GDP in the CEECs relative to the EU average}

\begin{tabular}{lcccccc}
\hline & 1980 & 1985 & 1991 & 1995 & 1999 & 2001 \\
\hline EU-9 & 1 & & & & & \\
EU-10 & & 1 & & & & \\
EU-15 & & & 1 & 1 & 1 & 1 \\
\hline Spain & 0.70 & 0.78 & 0.78 & 0.82 & 0.84 \\
Portugal & 0.55 & 0.68 & 0.69 & 0.72 & 0.69 \\
Greece & 0.65 & 0.65 & 0.63 & 0.61 & 0.62 & 0.64 \\
\hline Czech Republic & & & & 0.62 & 0.59 & 0.57 \\
Estonia & & & 0.34 & 0.39 & 0.42 \\
Poland & & & 0.34 & 0.39 & 0.40 \\
Slovenia & & & 0.63 & 0.68 & 0.69 \\
Hungary & & & 0.45 & 0.50 & 0.51 \\
\hline Slovakia & & & 0.46 & 0.49 & 0.48 \\
Latvia & & & 0.25 & 0.29 & 0.33 \\
Bulgaria & & & 0.33 & 0.28 & 0.28 \\
Lithuania & & & 0.32 & 0.34 & 0.38 \\
Romania & & & 0.28 & 0.24 & 0.25 \\
\hline
\end{tabular}

Sources : CEPII-CHELEM, Eurostat.

Catching-up patterns are rather specific in the CEECs. They have been transition economies but not underdeveloped ones. They were initially much industrialised and were endowed with skilled and low-cost labour forces. When compared with the EU levels, the share of manufacturing remains high both in terms of employment and value added, especially in the Czech Republic and Slovenia. While the share 
of manufacturing remains high, the increasing importance of services in value added is a relevant indicator of structural convergence, as it happened to be in the less advanced EU countries, such as Portugal or Greece (Midelfart-Knarvik et al., 2002). Tertiary activities represent more than $60 \%$ of the value added in most of the candidate countries (Poland, Hungary, Slovakia and the Baltic States). Moreover, the share of services developed faster than in countries where they were initially undersized. As tertiary industries are associated with non-tradable goods, they are much more dispersed than manufacturing activities and their development can restrict specialisation dynamics.

However, high structural disparities can be observed both vis-à-vis the EU and within the candidate countries. Wages and productivity differences are large. Slovenian nominal wages are more than twice as high as in other Central European countries while wages in Bulgaria and Romania remain the lowest. Although wage growth rates are higher in the candidate countries than in the EU, productivity gains allow them to keep a strong competitive advantage in terms of unit labour costs (including wages and social contributions). According to this index (chart 1), all the candidate countries are advantaged relative to the EU countries, especially in sectors sensitive to price competitiveness. Only Slovenia shows an index close to Greece while Bulgaria, Romania and Slovakia, where labour costs are only $10 \%$ of the EU average, still rank at the bottom of the table.

1. Relative unit labour costs in 2000

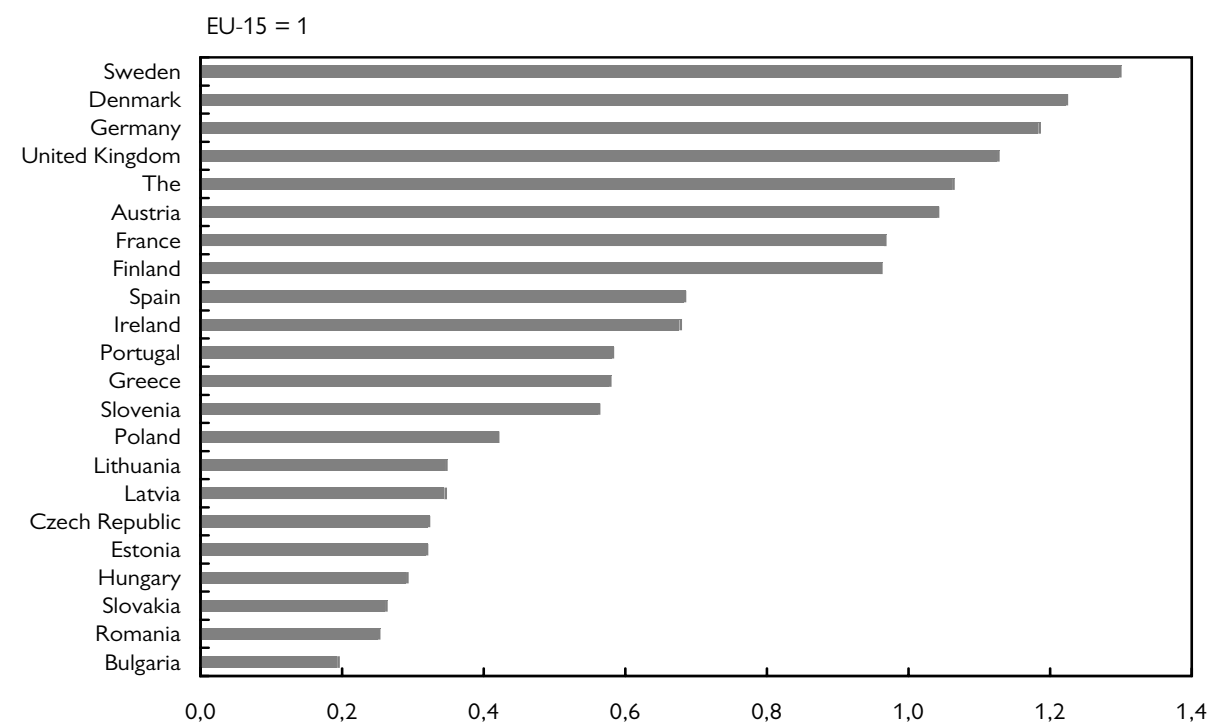

Sources: Eurostat, authors' calculations. 
Regarding skill levels, evidence in the candidate countries relative to the EU is mixed. Human capital measures are complex and unsatisfactory as they only take into account educational attainment and exclude experience and skills acquired throughout professional life ${ }^{7}$. Barro and Lee's (2000) human capital measure is an indicator of educational attainment. The accession countries are rather homogenous from this point of view. Except for Slovenia, the CEECs often benefit from higher educational levels than other developed countries. However, considering the education level of active people (Landesmann, 2003) discloses that around $30 \%$ of workers have not reached a secondary school level both in the candidate countries and in the more advanced EU members. This share reaches more than $40 \%$ in Bulgaria and Romania and even $60 \%$ in the Southern Europe. On the other hand, the EU members have a higher share of high-skilled workers (the share of active population with a tertiary education level), around $20 \%$, while it reaches no more than $14 \%$ in the CEECs. Finally, R\&D expenditures can provide a good approximation of economic and technological catching-up (table 2). Overall, the index is appreciably lower in the CEECs than in the EU, except in Slovenia and the Czech Republic where it converges towards the EU standards. Moreover, it has remained stable and even decreased in some cases because of budgetary restrictions linked to the transition process.

\section{2. $R \& D$ expenditures as a percentage of GDP}

\begin{tabular}{lll}
\hline & 1995 & 2000 \\
\hline Czech Republic & 1.01 & 1.33 \\
Poland & 0.69 & 0.70 \\
Hungary & 0.73 & 0.80 \\
Slovenia & 1.69 & 1.52 \\
Slovakia & 0.94 & 0.67 \\
Estonia & 0.61 & 0.66 \\
Latvia & 0.53 & 0.48 \\
Lithuania & 0.48 & 0.60 \\
Bulgaria & 0.62 & 0.52 \\
Romania & 0.80 & 0.37 \\
EU-15 & 1.89 & 1.93 \\
\hline
\end{tabular}

Source: Eurostat, 2002b.

7. A survey by Eurostat (2002a) on training throughout professional life in the accession countries usefully complements the usual data on educational level as a proxy for human capital. It shows that Czech and Estonian enterprises, especially the largest ones, invest massively for the training of their employees. By contrast, firms that do not invest in training mainly consider that their labour force already has appropriate skills. Thus, the survey provides useful information on the match between existing skills and the needs of a competitive market-based economy. 


\subsection{The likely effects of deeper EU integration on international specialisation}

As deeper integration is ongoing, inward FDI in the new EU incumbents can accelerate the emergence of two opposite patterns as regards industrial specialisation (Mouhoud, 1997).

First, we will characterise by inter-industry specialisation a development of trade flows based predominantly on differences in factor endowments. This can confine countries whose specialisation is driven by traditional and unskilled labour-intensive industries in a lowdevelopment trap. Instead of building conditions that would allow them to compete on global markets, some countries could attempt to exploit their own comparative advantages. The integration process may induce trade-diverting effects in favour of the new members. It would encourage in these countries a specialisation based on classical comparative advantages that could lock them in traditional sectors and reduce the opportunity for an intra-industry trade upgrading.

Second, intra-industry specialisation can be considered as the most favourable case. After the enlargement, the future EU will include both developed and backward countries. This could heighten the emergence of spillover effects that would play a great role in the definition of specialisation patterns. The transition countries are initially very industrialised and well endowed in physical capital, transport and telecommunications infrastructure, although necessitating modernisation and disconnected from EU networks. The project of future EU enlargement(s) was sufficiently credible for firms, anticipating the formal integration, to have decided for a long time past to establish production units or joint-venture agreements with the aim of benefiting from firstmover advantages in the perspective of expansion strategies on local markets. In this context, economic and technological catching-up processes can be enhanced and intra-industry trade can intensify.

Two distinct strategies as regards FDI can be associated with these two types of specialisation patterns. In the context of deeper interindustry specialisation, vertical-type multinational strategies dominate. Multinational firms disperse their production activities according to host countries' comparative advantages. The more labour-intensive production stages, such as assembly, are relocated in countries with cheaper labour forces. These newly established affiliates generate imports of intermediate goods and exports of final goods between home and host countries, as well as growing intra-firm trade. Given that this FDI is motivated by differences in factor endowments, they hasten an international division of labour which helps to reinforce interindustry specialisation patterns. 
In contrast, FDI is considered as horizontal when multinational firms are stimulated mainly by expansion on local markets. In that case, the ownership of specific asset or technological advantages allows a multinational firm to establish different production units in order to serve domestic markets and benefit from scale economies at the firm level and not only at the plant level. Foreign investors give priority to proximity as this means they can be more reactive to the preference of consumers for differentiated goods. This type of FDI is more likely to occur between countries whose preferences are similar (Brainard, 1993; Markusen, 1995). This investment depends on market access considerations and the search for complementarities in technology and know-how. It is then more likely to occur in technology-intensive industries or in sectors that produce non-tradable goods and services. It contributes both to increasing the number and improving the quality of products, and helps to reinforce intra-industry trade patterns, especially in quality-differentiated goods (Fontagné et al., 1998).

In the case of candidate countries, intra-industry specialisation is likely to be enhanced thanks to inward FDI, especially in the Central European ones (Hungary, Czech Republic, Slovenia, Slovakia, Estonia). However, in the more peripheral and lagging behind countries, FDI could contribute to the persistence of inter-industry specialisation. Until now, FDI has materialised in two main specific ways. First, foreign firms were associated with the mass privatisation programmes of former state-owned enterprises. While they have to share risks associated with the future profitability of the new entities, they benefit from being favourably positioned to gain local market shares. They can potentially bring technology and managerial methods that help the adaptation of transition economies. Second, FDI can be realised through joint-venture agreements and strategic alliances. Overall, mergers and acquisitions (including joint-venture agreements) have accounted for the bulk of FDI since the end of the eighties. In the case of CEECs, acquisitions are more frequent than the creation of wholly-owned affiliates because of privatisation programmes (Toubal, 2001).

\subsection{FDI trends in the CEECs}

Despite the world economic slowdown, inward FDI is still increasing in Eastern and Central Europe. Their transitional nature has favoured the attractiveness of FDI. In 2002, the stock of inward FDI in CEECs reached more than USD 146 billion, whereas it was marginal ten years ago (table 3). The share of FDI in the candidate countries' economies is significantly higher than their representation in the total world flow would suggest. In relative terms, FDI stock as a percentage of GDP is around 30\%, which is similar to the EU level, whereas the CEECs have received investment flows for only a dozen years. However, FDI 
stock in the CEECs remains low, compared with amounts located in the EU area. As the EU shifts from 15 countries to 25, inward European FDI stock will rise by only $4 \%$.

\section{The distribution of FDI stock in the candidate countries}

\begin{tabular}{lcccc}
\hline \multicolumn{1}{c}{2002} & $\begin{array}{c}\text { FDI stocks } \\
\text { (USD million) }\end{array}$ & $\begin{array}{c}\text { As a \% of } \\
\text { national GDP }\end{array}$ & $\begin{array}{r}\text { As a \% of } \\
\text { total CEECs }\end{array}$ & per inhabitant \\
\hline Czech Republic & 38,450 & 52.05 & 26.17 & 3,767 \\
Estonia & 4,226 & 61.21 & 2.88 & 3,105 \\
Slovenia & 5,074 & 21.70 & 3.45 & 2,545 \\
Hungary & 24,416 & 34.94 & 16.62 & 2,400 \\
Slovakia & 10,225 & 40.66 & 6.96 & 1,901 \\
\hline CEECs-10 & 146,920 & 30.09 & 100.00 & 1,427 \\
\hline Poland & 45,150 & 22.55 & 30.73 & 1,179 \\
Latvia & 2,723 & 30.46 & 1.85 & 1,161 \\
Lithuania & 3,981 & 26.63 & 2.71 & 1,145 \\
Bulgaria & 3,889 & 23.45 & 2.65 & 493 \\
Romania & 8,786 & 18.17 & 6.00 & 402 \\
\hline
\end{tabular}

Sources: UNCTAD and Eurostat, authors' calculations.

Within candidate countries, FDI is not uniformly distributed. In absolute terms, Poland, the Czech Republic and Hungary concentrate more than $75 \%$ of total FDI stock in the region while FDI in the Balkan and Baltic countries is rather low. In relative terms, concentration is much less evident since a small country such as Estonia has received the highest FDI stock as a percentage of GDP. As far as geographic source is concerned, FDI mainly comes from the EU (80\% in 2000). More precisely, half of total investment originates from three countries: the Netherlands, Germany and France, which became the largest investor country in 2000 with a $21 \%$ share, having been only $5 \%$ in $1998^{8}$.

Several factors explain such a rise in FDI towards CEECs. First, the new environment, especially the legal environment, allowed investors to engage in operations that were formerly unfeasible. Then, economic transition and real perspectives of integration with the EU have contributed to improve attractiveness. Second, specific characteristics of CEECs make them an attractive location for multinational firms. The availability of a relatively cheap and well-educated labour force is a strong advantage combined with a large-sized potential market (Dupuch

8. The Netherlands is a particular case as a source country: due to the presence of holding companies, so that investing firms are not fully Dutch and the share of FDI from the Netherlands is overestimated. 
and Milan, 2003). Moreover, privatisation programmes occurred while competition was still weak, which motivated multinational firms to engage in a race for first-mover-type advantages. Other forms of direct investment followed privatisations, such as major holdings in, and acquisition of, existing enterprises or the creation of ex nihilo production units.

Once the enlargement is concluded, new FDI flows are likely to occur in spite of the decline of privatisations for two reasons. First, the previous enlargement waves were followed by significant rises in FDI inflows into the new accession countries. This was particularly the case of Spain and Portugal after 1986 although Spain had at the same time liberalised its legal framework towards FDI while CEECs have already done so for a long time. Second, investors' uncertainty about economic, political and institutional stability will vanish with the formal accession of these economies to the EU. However, new amounts of FDI will depend on how large an integration effect has been expected by investors. Although the potential of FDI has largely been exploited in the past ten years, some countries such as Slovakia, Romania and Bulgaria could receive a non-negligible amount of FDI in the future (Henriot, 2003).

In spite of significant improvements in the recent years, available data relative to the industrial distribution of $\mathrm{FDI}$ in the CEECs remain relatively scarce. The first estimates published in 1997 by UNCTAD revealed that FDI was mainly located in tertiary activities in the most advanced transition countries (the Czech Republic, Hungary and Slovenia) and more importantly in manufacturing sectors and traditional activities in Poland and Romania. In the first case, this result highlights the potential positive role played by FDI in changing patterns of specialisation in these economies. As a consequence, the location of FDI in non-traditional industries is likely to favour the development of intraindustry trade with the EU countries. In the latter case, the concentration of FDI in home countries' comparative advantage industries is likely to reinforce specialisation in traditional industries 9 .

A recent study by Eurostat (2002b) based on 1999 FDI stock data confirms this view. With $54 \%$ of total inward investment in candidate countries, tertiary activities are the main recipient sector. It also reveals strong disparities across countries and distinguishes three groups of countries. The first one is the special case of Bulgaria, where manufacturing industries dominate the industrial distribution of inward FDI stock. Food industries, metals and chemicals are the main recipient sectors. We find in the second group Poland, Slovenia, Slovakia and the Czech Republic, where FDI is more balanced. Services account for 51 to $53 \%$ of total stock and particularly trade and financial activities. At the manufacturing level, some differences can be highlighted. Food

9. For the case of Poland, the reader is referred to Weresa (2001). 
products are an attractive industry in Poland. Metals, machinery and equipment goods receive the highest share of FDI in Slovakia. Chemicals are the main attractive sector in Slovenia. Finally, tertiary activities are strongly privileged (more than $2 / 3$ of total FDI stock) in the Baltic States, which form the last group. The main recipient sectors are trade and distribution, financial activities, and transport and telecommunications.

We adapted table 4 from Landesmann (2003) who collected stock data at the end of 2000 in a sample of CEECs. Overall, table 4 depicts the same picture as Eurostat data. FDI inflows are more intense in tertiary activities in Slovenia, the Czech Republic and Hungary than in other Central European countries such as Slovakia, where basic metals account for a significant share of FDI. The share of services is markedly higher in the Baltic States while manufacturing activities, such as food and automotive products (in Poland) and metals (in Slovakia), account for around half of manufacturing FDI.

We can go further in the analysis of FDI industrial distribution by adopting the classification proposed by Pavitt (1984), (see the appendix). This distinguishes traditional, scale-intensive and knowledgebased industries according to a more disaggregated industrial data set built from national sources in three countries (table 5).

Slovenia and the Czech Republic have rather similar shares of inward FDI in increasing-returns industries, which account for $68 \%$ to $74 \%$ of total FDI in manufacturing. In the Czech case, traditional industries still account for an important share. By contrast, Bulgaria displays a very different picture as the Eurostat survey already suggested: FDI stock is more abundant in manufacturing than in services. Moreover, traditional industries receive as much foreign investment as scale-intensive industries. Consequently, FDI in Bulgaria tends to reinforce existing comparative advantages and specialisation in labour-intensive industries whose competitiveness depends essentially on cost considerations.

To sum up, FDI inflows in the candidate countries are unevenly distributed across countries and across sectors. Foreign investments in medium-high technology industries with a high growth potential are noteworthy. As FDI favours the emergence of competitive firms that are able to influence the patterns of comparative advantages, foreign presence can play a key role in the transformation of manufacturing in host countries. Consequently, according to the two scenarios described earlier, we can distinguish countries where FDI benefits industries where host countries still have comparative advantages and countries where FDI is oriented towards the home country's comparative-advantage industries. 
However, it is difficult to distinguish vertical and horizontal types of FDI in the CEECs. On the one hand, cost advantages make them attractive for foreign firms' industrial relocation by means of both FDI and international subcontracting. In unskilled labour-intensive industries (for example assembly stages in clothing, leather, footwear or electrical materials) international subcontracting operations with the CEECs intensified in the beginning of the transition process, especially under outward-processing trade. These operations played a key role in the growth of manufacturing exports of these countries with the EU (Chevallier et al., 1999). Nevertheless, increasing labour costs during the transition process make such an advantage transitory, especially in the most advanced candidate countries (Resmini, 2000). On the other hand, weak potential demand can be perceived as a barrier to FDI for the purpose of penetrating Eastern markets. Nevertheless, increasing purchasing power and the perspective of formal integration make this aspect transitory again.

Considering that industries in which foreign firms mostly export their sales can be seen as the consequence of relocation strategies, Eltetö (1998) concludes that around 40\% of FDI in Hungary is the result of such a strategy while $60 \%$ is motivated by market access considerations. More recently, Aussillioux and Pajot (2001) showed that French $\mathrm{FDI}$ in the CEECs is driven by home country's comparative-advantage industries with the clear exception of Romania and Turkey where relocation strategies predominate.

As a consequence, FDI flows can contribute to the transformation of international specialisation and help to improve R\&D- and skilledlabour industrial content. Despite weak R\&D intensities, some of the candidate countries that were formerly endowed with national innovation systems are shifting from specialisation based on lowtechnology industries towards medium-to-high technology industries. In 1996, the CEECs mainly produced down- and medium-market goods but great differences exist in the structure of CEECs' trade with EU countries. Down-market goods represent $44 \%$ of Hungarian exports while the figure reaches $73 \%$ of Romanian exports. By contrast, the share of up-market goods varies from $31 \%$ in Slovenia and $28 \%$ in Hungary to a low 8\% in Romania. Between 1993 and 1996, the relative position in up-market products improved for all Central European countries, which strongly contrasts with the situation of Latvia, Lithuania and the Balkan countries. In the former case, this result excludes the scenario of locking specialisation in traditional sectors (Freudenberg and Lemoine, 1999) 


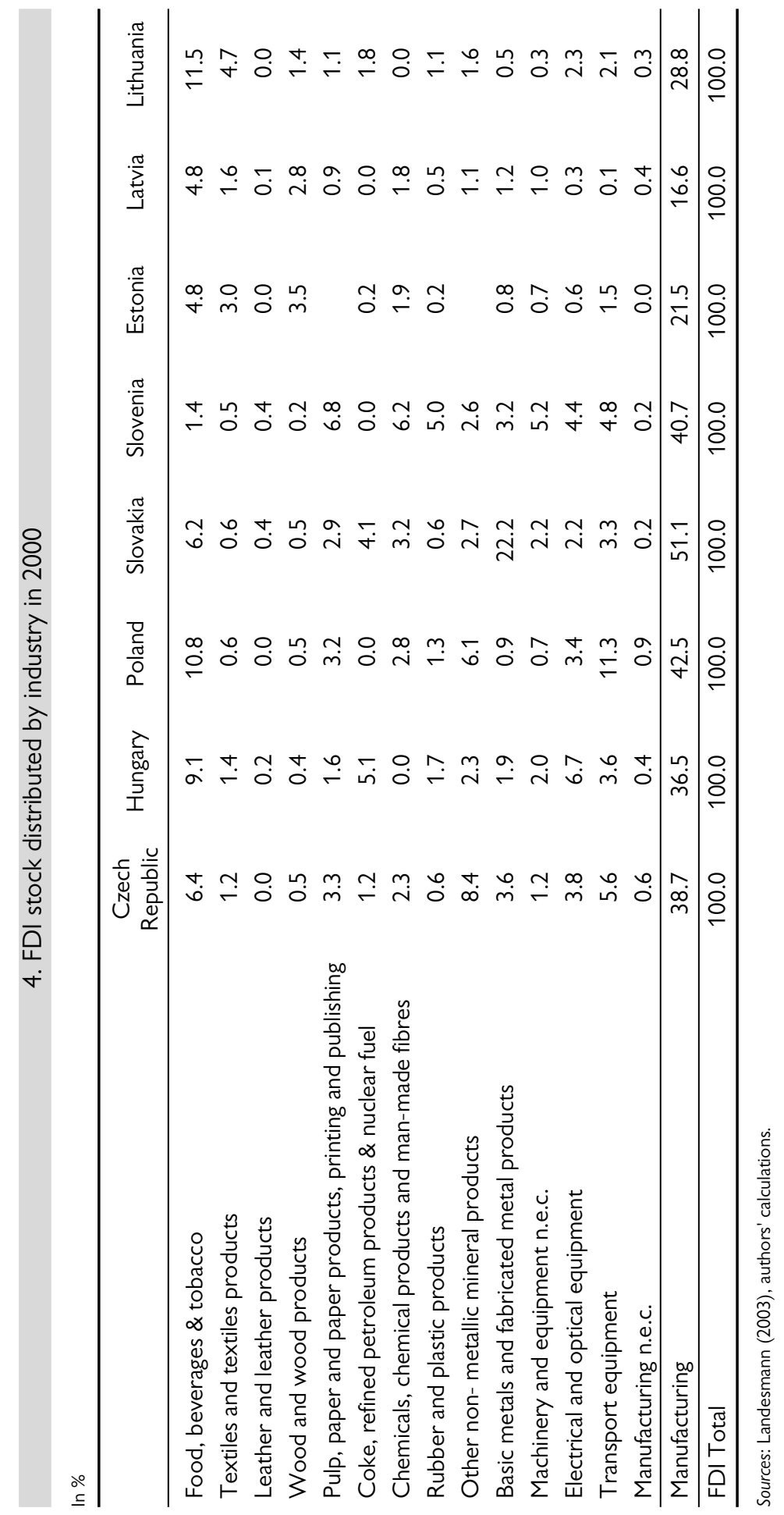


WHAT DOES IT CHANGE FOR THE EUROPEAN ECONOMIC GEOGRAPHY? I

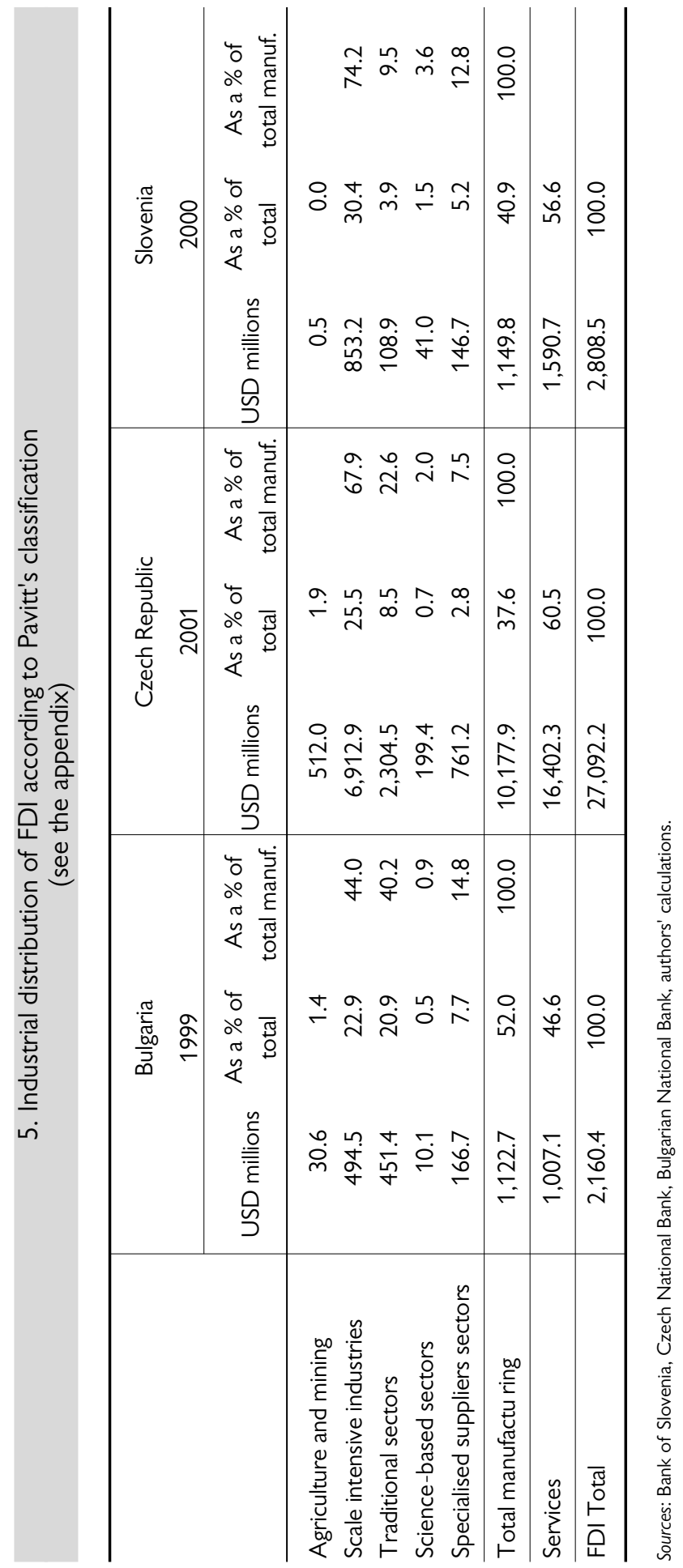




\section{Trade specialisation patterns in an enlarged Union}

\section{I. International specialisation in the EU-25}

Many papers have described empirical evidence on the location of activity in the $\mathrm{EU}^{10}$. The distribution of activities follows the same trend with an increasing relative concentration over the last two decades (Dupuch and Jennequin, 2001). Distinction between industrial characteristics provides more precise information. The European periphery predominantly attracts labour- and low-tech intensive activities whereas high-tech, high-skilled or increasing-returns-to-scaleintensive activities are more spatially agglomerated in the core regions (Midelfart-Knarvik et al., 2002).

While specialisation in the US seems to be declining, it has increased within the EU since the 1970's. Moreover, peripheral countries like Portugal, Finland and Greece exhibit a more pronounced specialisation than core countries (Dupuch et al., 2001). At the regional level, studies are quite mixed in their conclusions. No significant tendency emerges in the EU (Combes and Overman, 2003).

\section{The Krugman specialisation index}

Our measure of specialisation is provided by the Krugman index (1991a), which is computed for a country ' $a$ ' relative to a country ' $b$ '. Let us take an intuitive example. Suppose that two countries, ' $a$ ' and ' $b$ ', export the following amounts of each of the products.

\begin{tabular}{l|c|c|c|c}
\hline Product k & Value & $\begin{array}{c}\text { Share of product } \\
\text { in total exports } \\
v_{a}^{k}(t) \equiv x_{a}^{k}(t) / \sum_{k} x_{a}^{k}(t)\end{array}$ & $\begin{array}{c}\text { Value } \\
x_{b}^{k}(t)\end{array}$ & $\begin{array}{c}\text { Share of product } \\
\text { in total exports } \\
v_{b}^{k}(t) \equiv x_{b}^{k}(t) / \sum_{k} x_{b}^{k}(t)\end{array}$ \\
\hline 1 & 10 & 0,1 & 500 & 0,5 \\
2 & 90 & 0,9 & 500 & 0,5 \\
Total & 100 & 1 & 1,000 & 1 \\
\hline
\end{tabular}

For a period $t$, the Krugman specialisation index is defined by the formula: $K_{a, b}(t)=\sum_{k} a b s\left(v_{a}^{k}(t)-v_{b}^{k}(t)\right)$

with: $\quad v_{i}^{k}(t) \equiv x_{i}^{k}(t) / \sum_{k} x_{i}^{k}(t)$

10. For a survey of concentration and specialisation studies in the EU, see Combes and Overman (2003). Concerning the empirical literature based on the NEG models, see Overman et al. (2003) or Head and Mayer (2003). 
where $i=a, b . \quad x_{i}^{k}(t)$ can be exports, employment, production or value added data, disaggregated in $k$ industries. The index provides information on the difference between production structure $v_{i}^{k}(t)$ in a country ' $a$ ' and a reference country ' $b$ '. It ranges from zero when specialisation is nil to two when specialisation is complete. Contrary to other measures of absolute specialisation, such as the Herfindhal-Hirschmann index, the Krugman index is a relative one: it measures how specialised country ' $a$ ' stands relative to country ' $b$ '. In the text, the index is computed for a country ' $a$ ' relative to the EU-15.

In the example, the formula gives:

$$
K_{a, b}(t)=a b s(0.1-0.5)+a b s(0.9-0.5)=0.8 .
$$

We now turn to our own evaluation of international specialisation. We apply the Krugman index (see box 2) to the candidate countries and present EU Member States, using sectoral export data covering 72 products (table 6). The core and the largest countries are the least specialised. The peripheral countries, on the other hand, are more specialised than the EU average. In southern Europe, Spain's specialisation is rather stable while Portugal and Greece, initially highly specialised, have experienced a major diversification of their activities, which reveals a converging process of industrial structures with the EU average.

Differences in trade specialisation intensity are strong in an enlarged Union, with a clearly different pattern between core and peripheral countries. Moreover, huge disparities appear within the candidate countries. The Czech Republic, Hungary, Slovenia and Poland are more diversified than peripheral countries such as Portugal and Greece while the Balkan and Baltic countries exhibit the highest values of the Krugman index.

Geographic distance from the European core seems to matter as the most peripheral countries are also the most specialised. Candidate countries are generally specialised in resource-intensive industries (metals, wood and wood products) and labour-intensive industries (textiles and clothing) while maintaining comparative disadvantages in capital-intensive industries such as machinery, equipment goods or chemical products (Freudenberg and Lemoine, 1999). However, wide divergences appear among these countries and some of them are experiencing great changes in their trade specialisation. The most advanced CEECs are henceforth getting some new advantages in technology and capital-intensive sectors while still keeping comparative advantages in low-tech sectors (Boillot, 2003). For instance, Hungary achieved new specialisation in electronic and computer industries and Estonia in telecommunications at the same time keeping comparative advantages in food industries (in Hungary) and wood products (Estonia). By contrast, other Baltic states, Bulgaria and Romania and Poland to a lesser extent, still exhibit a high share of traditional activities (food products, metals, textiles) in their export structure. 
I Sébastien Dupuch, Hugues Jennequin and El Mouhoub Mouhoud

6. Export specialisation index for EU countries and the CEECs

\begin{tabular}{lllll}
\hline & $90-92$ & $93-95$ & $96-98$ & $99-00$ \\
\hline France & 0.288 & 0.287 & 0.279 & 0.270 \\
Bel-Lux & 0.523 & 0.517 & 0.498 & 0.451 \\
Germany & 0.310 & 0.319 & 0.325 & 0.340 \\
Italy & 0.482 & 0.503 & 0.531 & 0.534 \\
The Netherlands & 0.581 & 0.580 & 0.609 & 0.629 \\
United Kingdom & 0.419 & 0.431 & 0.407 & 0.429 \\
Ireland & 0.923 & 1.014 & 1.044 & 1.067 \\
Denmark & 0.684 & 0.689 & 0.662 & 0.639 \\
Finland & 0.885 & 0.887 & 0.902 & 0.968 \\
Sweden & 0.603 & 0.648 & 0.642 & 0.626 \\
Austria & 0.555 & 0.539 & 0.484 & 0.485 \\
Spain & 0.515 & 0.521 & 0.525 & 0.527 \\
Greece & 1.151 & 1.066 & 1.021 & 1.029 \\
Portugal & 0.922 & 0.913 & 0.837 & 0.822 \\
EU-15 & 0.449 & 0.461 & 0.465 & 0.473 \\
\hline Slovenia & & 0.662 & 0.662 & 0.690 \\
Estonia & & 0.949 & 0.949 & 1.110 \\
Latvia & & 1.172 & 1.223 & 1.312 \\
Lithuania & & 0.990 & 0.975 & 1.093 \\
Czech Republic & & 0.586 & 0.551 & 0.610 \\
Slovakia & & 0.681 & 0.646 & 0.713 \\
Hungary & 0.622 & 0.634 & 0.686 \\
Poland & & 0.832 & 0.741 & 0.736 \\
Romania & 0.980 & 1.074 & 1.097 \\
Bulgaria & 0.889 & 0.939 & 0.970 \\
\hline Sourcs CEn & & & & \\
\hline & & & & \\
\hline
\end{tabular}

Sources: CEPII-CHELEM, authors' calculations.

Table 7 provides information on the similarity in export structures within the CEECs on the one hand, and between the CEECs and the EU Member States on the other. First, central European countries have highly similar export structures relative to the EU, especially Spain and Portugal. If they follow a Spanish-type trend, countries such as Hungary and the Czech Republic and also, but to a lesser extent, Poland and Slovenia should avoid the risks generated by strong specialisation in traditional sectors. On the contrary, such an optimistic view cannot be held about the more peripheral countries. They appear more similar to Greece than to the rest of the EU. This is particularly the case of Bulgaria. Second, export structures in the candidate countries are especially far from those of Ireland, which experienced strong technological catch-up. However, the exception of Hungary is noteworthy 
with its index value relative to Ireland having a higher value than the other CEECs', suggesting the growing importance of high-technology industries in this country. Third, similarity of export structures within CEECs implies that the main competitors of the candidate countries are still the candidate countries themselves. For instance, Poland, the Czech Republic, Slovakia and Slovenia exhibit high values of the index ${ }^{11}$.

7. Finger-Kreinin similarity index (see box 3)

\begin{tabular}{|c|c|c|c|c|c|c|c|c|c|}
\hline $\begin{array}{l}\frac{\sigma}{\tilde{e}} \\
\frac{0}{\omega} \\
\frac{0}{\omega}\end{array}$ & 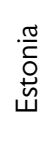 & $\sum_{\stackrel{J}{J}}^{\pi}$ & 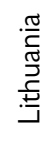 & 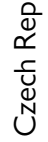 & $\frac{\frac{\pi}{\sqrt{n}}}{\frac{\partial}{n}}$ & 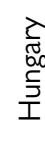 & & 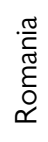 & $\begin{array}{l}\frac{\pi}{2} \\
\frac{\pi}{2} \\
\frac{0}{J} \\
0\end{array}$ \\
\hline
\end{tabular}

\begin{tabular}{|c|c|c|c|c|c|c|c|c|c|c|}
\hline Estonia & 0.410 & & & & & & & & & \\
\hline Latvia & 0.372 & 0.662 & & & & & & & & \\
\hline Lithuania & 0.434 & 0.629 & 0.617 & & & & & & & \\
\hline Czech Rep & 0.719 & 0.403 & 0.356 & 0.427 & & & & & & \\
\hline Slovakia & 0.721 & 0.428 & 0.418 & 0.474 & 0.738 & & & & & \\
\hline Hungary & 0.554 & 0.384 & 0.306 & 0.396 & 0.609 & 0.581 & & & & \\
\hline Poland & 0.734 & 0.463 & 0.415 & 0.513 & 0.704 & 0.662 & 0.600 & & & \\
\hline Romania & 0.490 & 0.481 & 0.464 & 0.587 & 0.466 & 0.559 & 0.438 & 0.566 & & \\
\hline Bulgaria & 0.480 & 0.409 & 0.45 & 0.565 & 0.446 & 0.573 & 0.424 & 0.548 & 0.661 & \\
\hline Spain & 0.644 & 0.397 & 0.342 & 0.443 & 0.713 & 0.729 & 0.596 & 0.642 & 0.468 & 0.511 \\
\hline Greece & 0.439 & 0.463 & 0.474 & 0.575 & 0.404 & 0.482 & 0.403 & 0.472 & 0.518 & 0.579 \\
\hline Portugal & 0.643 & 0.401 & 0.386 & 0.490 & 0.644 & 0.657 & 0.572 & 0.647 & 0.544 & 0.501 \\
\hline Ireland & 0.281 & 0.250 & 0.189 & 0.250 & 0.272 & 0.240 & 0.460 & 0.267 & 0.226 & 0.283 \\
\hline EU-15 & 0.654 & 0.421 & 0.345 & 0.457 & 0.690 & 0.639 & 0.673 & 0.641 & 0.463 & 0.512 \\
\hline
\end{tabular}

Source: CEPI-Chelem, author's calculations.

\section{The Finger-Kreinin index}

Our measure of export similarity is provided by Finger and Kreinin (1979). Now, suppose that two countries, ' $a$ ' and ' $b$ ', export the following amounts of each of the two products to a third country ' $c$ '.

\begin{tabular}{l|c|c|c|c}
\hline Product k & Value & $\begin{array}{c}\text { Share of product } \\
\text { in total exports } \\
v_{a, c}^{k} \equiv x_{a, c}^{k} / \sum_{k} x_{a, c}^{k}\end{array}$ & $\begin{array}{c}\text { Value } \\
x_{b, c}^{k}\end{array}$ & $\begin{array}{c}\text { Share of product } \\
\text { in total exports } \\
v_{b, c}^{k} \equiv x_{b, c}^{k} / \sum_{k} x_{b, c}^{k}\end{array}$ \\
\hline 1 & 10 & 0,1 & 500 & 0,5 \\
2 & 90 & 0,9 & 500 & 0,5 \\
\hline
\end{tabular}

11. This result can be found in other works (Chevallier et al., 1999). 
The 'export similarity' measure, computed using the following formula:

$$
F K_{a b, c}=\sum_{k} \min \left[v_{a, c}^{k} ; v_{b, c}^{k}\right]
$$

gives: $\quad F K_{a b, c}=\min (0.1 ; 0.5)+\min (0.9 ; 0.5)=0.6$.

In the text, the index is used in order to compare export structures between two countries ' $a$ ' and ' $b$ ' with the rest of the world (country ' $c$ ' in the formula). If the two countries ' $a$ ' and ' $b$ ' export the same goods to the third market, the index will take on a value of 1 . If export structures are completely dissimilar, the index will be zero.

\subsection{Moving towards an intra-industry specialisation?}

Specialisation indices and trends in intra-industry trade between EU countries and the CEECs provide similar conclusions. European trade is essentially intra-industry, especially in vertical differentiation, whose increase has been noteworthy since 1985. However, peripheral countries are an exception as regards this trend: inter-industry trade still predominates, despite a tangible catch-up experienced in Spain and to a lesser extent in Portugal. Analysing trade patterns between the $\mathrm{EU}$ and the candidate countries shows that inter-industry trade prevails and that large differences characterise the future EU members.

Considering data from different sources, three distinct groups can be highlighted (table 8). First, the Central European countries (Hungary, Slovenia and the Czech Republic) exhibit a high share of intra-industry trade which outweighs that of Portugal and Greece. Poland and Slovakia stand at a more intermediate level whereas inter-industry trade remains very predominant in both the Balkan and Baltic countries (from $85 \%$ to 95\%). Intra-industry trade in goods differentiated by quality (i.e. vertically) represents 80 to $90 \%$ of total intra-industry trade and has experienced a significant rise between 1993 and 1996, which argues in favour of an early convergence process of trade structures towards the EU standards. This shift appears more clearly in countries which had initially large amounts of intra-industry trade, which could mean larger and larger disparities within the candidate countries. According to Freudenberg and Lemoine (1999), some caveats subsist: is the convergence suggested by trade patterns robust? Do production structures follow the same trend? For institutional reasons (inefficiency in corporate governance and residual state ownership in the capital of newly private firms), the slow restructuring is the weak aspect of transition and can hamper the convergence process (Andreff, 1999). 
WHAT DOES IT CHANGE FOR THE EUROPEAN ECONOMIC GEOGRAPHY? I

8. Intra-industry trade in the EU and the CEECs

\begin{tabular}{|c|c|c|c|}
\hline \multirow{2}{*}{$\begin{array}{l}1996 \\
\text { (variation 1993-1996) }\end{array}$} & \multicolumn{2}{|c|}{ Intra-industry trade } & \multirow[t]{2}{*}{ Inter-industry trade } \\
\hline & Horizontal & Vertical & \\
\hline Czech Republic & $\begin{array}{c}9.6 \\
(5.8)\end{array}$ & $\begin{array}{l}38.1 \\
(5.5)\end{array}$ & $\begin{array}{c}52.3 \\
(-11.3)\end{array}$ \\
\hline Hungary & $\begin{array}{c}6.4 \\
(1.9)\end{array}$ & $\begin{array}{c}30.9 \\
(3.2)\end{array}$ & $\begin{array}{c}62.7 \\
(-5.1)\end{array}$ \\
\hline Slovenia & $\begin{array}{c}4.8 \\
(-4.2)\end{array}$ & $\begin{array}{l}27.3 \\
(4.0)\end{array}$ & $\begin{array}{l}67.9 \\
(0.2)\end{array}$ \\
\hline Slovakia & $\begin{array}{l}5.7 \\
(2.0)\end{array}$ & $\begin{array}{l}19.7 \\
(5.5)\end{array}$ & $\begin{array}{l}74.6 \\
(-7.5)\end{array}$ \\
\hline Poland & $\begin{array}{c}2.7 \\
(-2.3)\end{array}$ & $\begin{array}{l}20.6 \\
(5.0)\end{array}$ & $\begin{array}{l}76.6 \\
(-2.7)\end{array}$ \\
\hline Romania & $\begin{array}{c}1.7 \\
(-1.0)\end{array}$ & $\begin{array}{l}13.3 \\
(4.9)\end{array}$ & $\begin{array}{l}85 \\
(-3.9)\end{array}$ \\
\hline Bulgaria & $\begin{array}{c}2.6 \\
(0.7)\end{array}$ & $\begin{array}{l}11.2 \\
(1.3)\end{array}$ & $\begin{array}{l}86.3 \\
(-2.1)\end{array}$ \\
\hline Lithuania & $\begin{array}{l}1.1 \\
(0)\end{array}$ & $\begin{array}{c}5.9 \\
(3.6)\end{array}$ & $\begin{array}{l}92.9 \\
(-3.6)\end{array}$ \\
\hline Latvia & $\begin{array}{l}0.9 \\
(0.4)\end{array}$ & $\begin{array}{c}4 \\
(1.9)\end{array}$ & $\begin{array}{l}95.1 \\
(-2.3)\end{array}$ \\
\hline Estonia & $\begin{array}{c}0.8 \\
(0.3)\end{array}$ & $\begin{array}{c}3.5 \\
(0.4)\end{array}$ & $\begin{array}{l}95.7 \\
(-0.8)\end{array}$ \\
\hline EU-12 (1980) & 18.08 & 35.36 & 46.57 \\
\hline EU-12 (1985) & 17.94 & 34.54 & 47.52 \\
\hline EU-12 (1994) & 19.23 & 42.28 & 38.5 \\
\hline Greece (1980) & 2.02 & 11.33 & 86.65 \\
\hline Greece (1995) & 4.60 & 9.00 & 86.50 \\
\hline Spain (1985) & 10.12 & 26.35 & 63.52 \\
\hline Spain (1995) & 19.50 & 34.20 & 46.40 \\
\hline Portugal (1985) & 4.13 & 10.45 & 85.42 \\
\hline Portugal (1995) & 10.50 & 22.10 & 67.40 \\
\hline
\end{tabular}

Sources: for CEECs, Freudenberg and Lemoine, 1999 and for EU countries, Fontagné et al., 1998. 


\section{What about the Southern and Eastern Mediterranean Countries?}

Finally, we analyse the European trade linkages with a sample of Mediterranean countries having an association agreement with the EU. If we assume a large integrated area including Mediterranean countries, the question is how heterogeneous this area would be and how the implied divergences across nations would add to the regional divergence process within European nations. Table 9 summarises trade specialisation indicators for Turkey, the Maghreb countries and Egypt, compared with EU members and the candidate countries.

Mediterranean countries have very complementary trade structures relative to the EU. According to the Krugman index, they are the most specialised of the sample, except Turkey whose index has quickly decreased and is close to indices registered in the less advanced candidate countries. Morocco, Tunisia and Egypt exhibit similar values of the index. Algeria, on the contrary, displays very strong specialisation, due to predominant exports of gas and petroleum products. All these countries export a large share of low-value-added manufactured goods. For example, textiles account for a significant share of exports in Morocco, Tunisia and Turkey. They also display strong comparative advantages in food and resource-intensive industries. Finally, Egypt experiences trade advantages in petroleum products.

9. Specialisation and trade structures indices in the SEMCs

\begin{tabular}{lcccccc}
\hline & $\begin{array}{c}\text { Krugman } \\
\text { index } \\
1996-1999\end{array}$ & $\begin{array}{c}\text { Finger- } \\
\text { Kreinin } \\
\text { index } \\
\text { relative to } \\
\text { EU-15 } \\
(1999)\end{array}$ & $\begin{array}{c}\text { Finger- } \\
\text { Kreinin } \\
\text { index } \\
\text { relative to } \\
\text { CEECs-10 } \\
(1999)\end{array}$ & $\begin{array}{c}\text { Horizontal } \\
\text { Intra- } \\
\text { industry } \\
\text { trade } \\
(1996)^{* *}\end{array}$ & $\begin{array}{c}\text { Vertical } \\
\text { Intra- } \\
\text { industry } \\
\text { trade } \\
(1996)^{* *}\end{array}$ & $\begin{array}{c}\text { Inter- } \\
\text { industry } \\
\text { trade } \\
(1996)^{* *}\end{array}$ \\
\hline EU-15 & $0.464^{*}$ & & 0.730 & 17.5 & 41.6 & 40.9 \\
CEECs-10 & $0.746^{*}$ & 0.730 & & 5.0 & 24.8 & 70.2 \\
Algeria & 1.826 & 0.081 & 0.068 & 0.6 & 1.1 & 98.4 \\
Egypt & 1.370 & 0.333 & 0.393 & 1.0 & 3.1 & 95.9 \\
Morocco & 1.448 & 0.273 & 0.341 & 3.4 & 5.4 & 91.2 \\
Tunisia & 1.375 & 0.305 & 0.397 & 4.1 & 15.2 & 80.6 \\
Turkey & 1.043 & 0.502 & 0.576 & 6.1 & 10.2 & 83.7 \\
\hline
\end{tabular}

* Weighted average.

**Intra-industry trade shares are given relative to the EU.

Source: Dupuch and al., 2004.

As regards similarity in trade structures, the SEMCs are much more different from the EU than the candidate countries, except Turkey. Conversely, the Mediterranean countries are rather complementary to the EU according to the Finger index (with Morocco, Tunisia and Egypt 
displaying similar values) while Algeria exhibits very low values of the index, which result from their strong dependency on resource-intensive industries.

Shares of intra-industry trade and specialisation indices depict almost similar evidence. Overall, the Mediterranean countries have very high levels of inter-industry trade. Only Tunisia and Turkey display a substantial share of intra-industry trade close to $20 \%$, which ranks above the levels reached by the less advanced CEECs and the Baltic States. However, intra-industry trade is predominantly of the vertical type (i.e. traded goods are differentiated in quality ranges). Conversely, trade structures in Algeria, Morocco and Egypt are strongly biased towards inter-industry trade. Turning to sectoral considerations, intra-industry trade is much more significant in electric and electronic materials than in more traditional activities (20\% of electronics in Egypt and Morocco, around $26 \%$ of mechanical components and almost $30 \%$ of vehicles in EU-Turkey trade). Tunisia's trade is more specific as textiles account for the bulk of intra-industry trade. However, these figures result more from the more intermediate-goods-intensive nature of these industries than from the ability of countries to attract FDI and develop long-term comparative advantages in these sectors.

Consequently, differences across locations are still relevant. On the one hand, some evidence for diversification emerges from trade structures in a small number of candidate countries, which now display comparative advantages in higher-value-added industries. On the other hand, Mediterranean countries and the more peripheral Eastern countries remain specialised in resource- and labour-intensive industries and appear very complementary to the EU. Some recent works have shown some elements of trade diversification and quality upgrading, but these remain marginal (Chevallier and Freudenberg, 2001). Moreover, countries which experience shifts in intra-industry trade based on textiles and clothing industries, like Tunisia, are likely to suffer more from the competition coming from China's entry into the WTO and the future dismantling of the multi-fibre arrangement than from the accession of some CEECs to the EU.

\section{Conclusion}

The EU enlargement process, bringing in southern and eastern Mediterranean countries, is noteworthy for many reasons. The next enlargement wave is the largest and the most complex the EU has ever had to deal with since its creation. It encompasses countries that are more lagging behind in terms of economic performance than were Spain, Greece and Portugal when they joined the EEC in the eighties. 
Moreover, the CEECs are emerging from 12 years of transition that profoundly and rapidly modified their economic and productive structures. Under these conditions, this new stage in the European unification may influence the economic geography both within and between the Member States more than the preceding waves did.

Theoretically, in spite of the lack of labour mobility within the EU, a core-periphery schema is expected to occur as a result of vertical linkages. In terms of efficiency, the decrease in transaction costs and the gains from agglomeration compound each other. Consequently, sectoral divergence exhibited by the vertical-linkage models can find evidence in the EU through a high-skilled core attracting increasing intensive activities and a low-skilled periphery. These predictions are confronted with data relative to the main stylised facts on real and structural convergence of the candidate countries with the EU.

Two alternative scenarios are discussed. We show strong differences in trade specialisation intensity in an enlarged Union, with a clearly different pattern between core countries and the periphery. The former tend to converge towards the EU standards through the development of intra-industry trade and the upgrading of specialisation patterns while the latter remain dependent on comparative advantages in low-tech and labour-intensive sectors. The role of FDI in the host countries' specialisation pattern changes has been examined in this paper. The consequences of FDI in the CEECs' international specialisation cannot be denied. In the Spanish case and in some of the candidate countries, inward FDI has already played an important role in the shift towards intra-industry specialisation. In fact, foreign firms are likely to bring with them technology, know-how and management structures that help the transition process towards a competitive market-based economy. In the case of Mediterranean countries, benefits from FDI have been negligible until now. In the last years and despite the Euromed agreement, FDI inflows have remained low for various reasons such as unfavourable institutional framework, the slow pace of privatisation, macroeconomic uncertainty and small market size.

Finally, the picture of a diversified Europe in which nations keep the bulk of activities should not be altered with the enlargement for the core countries, including some peripheral countries and some new CEEC candidates for enlargement. The core-periphery schema is likely to persist, with a larger core including Slovenia, a few urban and border Hungarian and Polish regions, the Czech Republic and Slovakia while the EU periphery is enlarged to other Eastern and Mediterranean countries. In this context, the lack of a regulatory framework at the EU level in such a heterogeneous area could induce both economic and political tensions. Contrary to its founders' intentions, the result would be to reduce the large EU to, more or less, a free trade area. 


\section{References}

Amiti, M. and Pissarides, C. (2002). Trade and Industrial Location with Heterogeneous Labour, Centre for Economic Performance, DP 0541, August.

Andreff, W. (1999). 'Privatisation et Gouvernement d'Entreprise dans les économies en transition', Économie Internationale, $\mathrm{No}^{\circ}$ 77, pp. 97-129.

Aussilloux, V. M. and Pajot (2001). Enjeux Commerciaux de l'Élargissement de l'Union Européenne, Fourgeaud seminar, Direction de la Prévision, Ministry of the Economy and Finances, February.

Bailly F., Mouhoud, E. M. and Oudinet, J. (2003). 'Union européenne : Les nouvelles dynamiques migratoires : relance et complexification', Chronique Internationale de I'IRES, No 84.

Baldwin, R. E. (1994). Towards an Integrated Europe, Centre for Economic Policy Research, London.

Baldwin, R. E. (2001). 'Core-Periphery Model with Forward-looking Expectations', Regional Science and Urban Economics 31, pp. 21-49.

Baldwin, R. E., Forslid, R., Martin, P., Ottaviano, G.I.P. and RobertNicoud F. (2003). Economic Geography and Public Policy, Princeton University Press, Princeton.

Baldwin, R. E., Francois, J. and Portes, R. (1997). 'The Costs and Benefits of Eastern Enlargement: the Impact on the EU and Central Europe', Economic Policy 24, pp. 125-176.

Barro, R. and Lee, J. W. (2000). 'International Data on Educational Attainment: Updates and Implications', CID Working Paper No 42.

Bchir, M. H. and Maurel, M. (2002). 'Impacts économiques et sociaux de l'élargissement pour l'Union Européenne et la France', CEPII Working Paper, No 2002-03, avril.

Boillot, J. J. (2003). L’Union Européenne élargie, un défi économique pour tous, La Documentation Française.

Brainard, S. L. (1993). 'A Simple Theory of Multinational Corporations and Trade with a Trade-off between Proximity and Concentration', NBER Working Paper, No 4269.

Chevallier, A. and Freudenberg, M. (2001). 'La nature des Échanges Euro-méditerranéens et les perspectives d'intégration régionale', in Dessus $\mathrm{S}$ and J. Devlin, Vers une intégration régionale Arabe Euroméditerranéenne, Centre de Développement de l'OCDE, pp. 53-91. 
Chevallier, A., Lemoine, F. and Neyman, L. (1999). 'L’Union européenne et sa périphérie, conséquences de l'intégration commerciale de l'Europe centrale', Revue Économique, vol. 50, No 6, pp. 1169-1184.

Combes, P.P. and Overman, H. (2003). 'The Spatial Distribution of Economic Activities in the European Union', in Handbook of Regional and Urban Economics Volume IV, edited by V. Henderson and J. F. Thisse.

Commissariat Général du Plan (CGP) (1999). Scénario pour une Nouvelle Géographie Économique de l'Europe, Économica, Paris.

Dixit, A. K. and Stiglitz, J. E. (1977). 'Monopolistic Competition and Optimum Product Diversity', American Economic Review 67, pp. 297-308.

Dupuch, S. and Jennequin, H. (2001). 'Intégration régionale et géographie économique européenne : quelques résultats empiriques', CEPN Working Paper 04-2001.

Dupuch, S., Jennequin, H. and Mouhoud, E.M. (2001). 'Intégration européenne, élargissement aux PECO et économie géographique', Région et Développement, 2001-13, pp. 125-162.

Dupuch, S. and Milan, C. (2003). 'Les déterminants des investissements directs européens dans les pays d'Europe centrale et orientale', CEPN Working Paper 07-2003.

Dupuch, S., Mouhoud, E.M. and Talahite, F. (2004). 'Les Perspectives d'intégration entre l'Union européenne, les PECO et les pays sudméditerranéens : incidences sur les tendances de la spécialisation des activités en Europe', Économie Internationale, forthcoming.

Eltetö, A. (1998). 'Economic Performance of Foreign Investment Enterprises, Effects of FDI in Hungary', Institute for World Economics, Budapest, mimeo.

Emerson, M. and al. (1990). One market, one money, Oxford, Oxford University Press.

Eurostat (2002a). 'Première enquête sur la formation professionnelle continue en entreprise dans les pays candidats', Statistiques en Bref, Thème $3,2 / 2002$.

Eurostat (2002b). 'Investissements directs étrangers dans les pays candidats : répartition par secteur d'activité et par pays investisseur', Statistiques en Bref, Thème 2, 55/2002.

Finger, J. M., and Kreinin, M. E. (1979). 'A Measure of Export Similarity and its Possible Uses', The Economic Journal, vol. 89, pp. 905-912. 
Fontagné L., Freudenberg, M. and Péridy, N. (1998). 'Intra-Industry Trade and the Single Market: Quality Matters', CEPR Discussion Paper No 1953.

Forslid, R., Haaland, J., Maestad, O., and Midelfart-Knarvik, K. H. (2002a). 'Integration and Transition: Scenarios for Locations of Production and Trade in Europe', Economics of Transition, vol. 10 (1), pp. 93-117.

Forslid, R., Haaland, J. and Midelfart-Knarvik, K.H. (2002b). 'A U-shaped Europe? A Simulation Study of Industrial Location', Journal of International Economics 57, pp. 273-297.

Francois, J. (2002). 'Factor Mobility, Economic Integration, and the Location of Industry', in Economic Impact of EU Membership on Entrants: New Methods and Issues, R.E. Baldwin and A. Brunetti Volume Editors, Kluwer Academic Publishers: Boston/Dordrecht/London.

Frankel, J. and Rose, A. (1998). 'The Endogeneity of Optimum Currency Criteria', The Economic Journal, vol. 108, pp. 1009-1025.

Freudenberg, M. and Lemoine, F. (1999). 'Central and Eastern European Countries in the International Division of Labour in Europe', CEPII Working Paper No 1999-05.

Fujita, M., Krugman, P. and Venables, A. (1999). The Spatial Economy. Cities, Regions and International Trade, MIT Press, Cambridge, MA.

Head, K. and Mayer, T. (2003). 'The Empirics of Agglomeration and Trade', in Handbook of Regional and Urban Economics Volume IV, edited by V. Henderson and J.F. Thisse.

Henriot, A. (2003). 'Prospects for the Location of Industrial Activities after EU Enlargement', COE Working Paper, No 61, January.

Hirshman, A. O. (1958). The Strategy of Economic Development, Yale University Press, New Haven, CT.

Jennequin, H. (2003). 'Secteur tertiaire différencié et qualification de la main-d'œuvre, un modèle d'économie géographique tri-sectoriel', CEPN Working Paper 13-2003.

Krugman, P. R. and Venables, A. (1995). 'Globalization and the Inequality of Nations', Quarterly Journal of Economics, 110(4), pp. 857-880.

Krugman P. R. (1980). 'Scale Economies, Product Differentiation and the Pattern of Trade', American Economic Review 70, pp. 950-959.

Krugman, P. R. (1991a). Geography and Trade, MIT Press.

Krugman, P. R. (1991b). 'Increasing Returns and Economic Geography', Journal of Political Economy 99, pp. 483-499. 
Landesmann, M. (2003). Structural features of economic integration in an Enlarged Europe: patterns of catching-up and industrial specialisation, Economic Papers No 181, DG Economy and Finance, European Commission.

Ludema, R. and Wooton, I. (1999). 'Regional Integration, Trade, and Migration: Are Demand Linkage Relevant in Europe?', in Migration the Controversies and the Evidence, Faini R., de Melo J. and K. Zimmermann (eds.), CEPR London.

Manzocchi, S. and Ottaviano, G. I. P. (2001). 'Outsiders in Economic Integration: the Case of a Transition Economy', Economics of Transition, vol. 9 (1), pp. 229-249.

Markusen, J. R. (1995). 'The Boundaries of Multinational Enterprises and the Theory of International Trade', Journal of Economic Perspectives, vol.9, No 2, pp. 169-189.

Midelfart-Knarvik, K. H., Overman, H., Redding, S. and Venables, A. (2002). 'Integration and Industrial Specialisation in the European Union', Revue Économique, 53(3), pp. 469-481.

Mouhoud, E. M. (1997). 'The Links between Migration, Free Trade and Regional Integration: specific characteristics of the CEECs', in Migration, Free Trade and Regional Integration in Central and Eastern Europe, OECD WIFO, Verlag Österreich, Wien.

Neary, J. P. (2001). 'Of Hype and Hyperbolas: Introducing the New Economic Geography', Journal of Economic Literature, vol. 39:2, June, Pp. 536-561.

Ottaviano, G. I. P. and Puga, D. (1998). 'Agglomeration in the Global Economy: a Survey of the New Economic Geography', The World Economy 21, pp.707-731.

Ottaviano, G. I. P. and Thisse, J. F. (2001). 'On Economic Geography in Economic Theory: Increasing Returns and Pecuniary Externalities', Journal of Economic Geography 1, pp. 153-179.

Ottaviano, G. I. P. and Thisse, J. F. (2003). 'Agglomeration and Economic Geography', in Handbook of Regional and Urban Economics Volume IV, edited by V. Henderson and J. F. Thisse

Overman, H., Redding, S. and Venables, A. (2003). 'The Economic Geography of Trade, Production, and Income: A Survey of Empirics', in The Handbook of International Trade J. Harrigan and K. Choi (eds.), Basil Blackwell., Oxford.

Pavitt, K (1984). 'Sectoral Patterns of Technical change: Towards a Taxonomy and Theory', Research Policy, vol. 13(6), pp. 343-373.

Puga, D. (1999). 'The Rise and Fall of Regional Inequalities', European Economic Review 43, pp. 303-334. 
Puga, D. and Venables, A. (1999). 'Agglomeration and Economic Development: Import Substitution vs. Trade Liberalisation', Economic Journal, volume 109, Issue 455, pp. 292-311.

Resmini, L. (2000). 'The Determinants of Foreign Direct Investment in the CEECs, New Evidence From Sectoral Patterns', The Economics of Transition, vol. 8, No 3, pp. 665-689.

Rieber, A. and Tran, T. A. D. (2002). 'Technology Diffusion, NorthSouth Spillovers and Industrial Location', Journal of Economic Development, vol. 27, Issue 1, June, Pp. 25-40.

Tabuchi, T. and Thisse, J. F. (2002). 'Taste Heterogeneity, Labor Mobility and Economic Geography', Journal of Development Economics, vol.69, Issue 1, October, pp. 155-177.

Toubal L. F. (2001). 'Le capital étranger en Europe centrale et orientale', Le courrier des pays de l'Est, No 1313.

Venables A. (1996). 'Equilibrium Locations of Vertically Linked Industries', International Economic Review 37 (2), pp. 341-359.

Weresa M. (2001). 'The impact of foreign direct investment on Poland's trade with European Union', Post-Communist Economies, vol. 13, No 1. 


\section{APPENDIX:}

\section{The Pavitt classification}

Pavitt (1984) has developed a sectoral taxonomy of sectors of production and use of innovation. He identifies four major groups of sectors, with respect of the source of the innovations that they use and to the influence of science on the industrial performance.

- 'Supplier-dominated' sectors are broadly traditional industries in which innovative activity is rather limited to adaptation of new capital equipments and intermediate inputs which have been developed and produced by upstream suppliers. They include textile, clothing, leather, printing and publishing, wood products).

- 'Scale-intensive' industries mostly rely on scale economies in production and design or R\&D provided both internally or by equipment suppliers. This group includes transport equipment, cars, electrical consumer durables, metal manufacturing, parts of the chemical industry...

- 'Specialised supplier' industries embody a specialised knowledge in design and equipment-building. They generate products aimed at specific applications, market segments or single users. Typically, this group includes mechanical and instruments engineering.

- 'Science-based' sectors include the electronics industries and most of the chemical industries (pharmaceuticals). Major innovations as well as the improvements in process yields are frequent in these sectors where R\&D and laboratories are key elements. A high proportion of their product innovation enters a wide number of sectors as capital or intermediate inputs. 